\title{
Pengaruh Limbah Padi dan Pupuk Kandang Terhadap Pertumbuhan Bibit Tembakau Virginia (Nicotiana tabacum L.)
}

DOI 10.18196/pt.2016.064.112-115

\author{
Hariyono \\ Program Studi Agroteknologi, Fakultas Pertanian, Universitas Muhammadiyah Yogyakarta, \\ Jl. Lingkar Selatan, Kasihan, Bantul, Yogyakarta 55183, Indonesia, Telp. 0274387656 , \\ e-mail:hary@umy.ac.id
}

\begin{abstract}
ABSTRAK
Penelitian yang berjudul Pengaruh Limbah Padi dan Pupuk Kandang Terhadap Pertumbuhan. Bibit Tembakau Virginia (Nicotiana tabacumL.) telah dilakanakan untuk mengetahui jenis limbah padi dan pupuk kandang yang sesuai untuk pembibutan tembakau Virginia. Penelitian dilakukan di lahan percobaan yang terletak di Pakis, Delaggu, Klaten. Penelitian dilaksanakan dengan metode percobaan dalam pot faktorial 3 x 4 yang disusun dalam Rancangan Acak Lengkap. Faktor pertama yaitu macam limbah padi terdiri atas tiga jenis yaitu jerami, dedak, dan sekam. Faktor kedua yaitu empat macam pupuk kandang (PPK) yaitu tanah (control), tanah + PPK sapi, tanah + PPK kambing, tanah + PPK ayam, sehingga diperoleh 12 kombinasi perlakuan. Tiap kombinasi perlakuan terdiri atas 3 polibag dan masing-masing kombinasi perlakuan diulang tiga kali. Hasil penelitian menunjukkan bahwa limbah jerami padi dan pupuk kandang ayam adalah kombinasi yang terbaik untuk pembibitan Tembakau Virginia.

Kata Kunci: Tembakau, Limbah padi, Pupuk kandang, Seedling
\end{abstract}

\begin{abstract}
The experiment entitled the effect of using composisition rice residues and animal manure for media utilization on growth seedling of Virginia tobacco (Nicotiana tabacum L.) in seedbad was conducted to determine the approriate kind of rice residues and animal manure for seedbad for Virginia tobacco. The experiment was conducted at Pakis, Delanggu. The factorial experiment was arranged in the Complete Randomized Design with 12 combinations of treatment. The first factor was kinds of rice residues consisted: rice Straw, rice chaff, and rice bran. The second factor was kinds of animal manure consisted of manure of cow, manure of goat, and manure of chicken. The results of experiment showed that combination of rice straw and manure of chicken is the best treatment for seedling the tobacco Virginia.

Keywords: Tobacco, Rice residues, Animal manure, Seed waste
\end{abstract}

\section{PENDAHULUAN}

Usaha penanaman tembakau di Indonesia belum mengalami kemajuan yang berarti. Dibandingkan dengan produksi rata-rata dunia, maka produksi tembakau virginia di Indonesia terlampau rendah, apalagi bila dibandingkan dengan produksi tembakau virginia di Amerika Serikat. Oleh karena itu peningkatan kualitas dan produksi pada tembakau merupakan usaha-usaha teknis yang perlu dilakukan untuk menjaga kesinambungan devisa negara di sektor perkebunan (Hartana, 1980).

Abdullah dan Soedarmanto (1979) menyatakan bahwa kualitas suatu tembakau sangatlah dipengaruhi oleh keadaan lingkungan, dalam hal ini faktor iklim dan tanah. Untuk memperoleh hasil yang baik, yang perlu diperhatikan adalah: bibit yang digunakan, pengolahan tanah, pemupukan, pengairan, pemanenan dan pasca panen.

Pemilihan benih untuk pembibitan merupakan persoalan yang tidak dapat diabaikan. Benih tembakau yang akan ditanam sebaiknya diketahui terlebih dahulu daya kecambahnya. Daya kecambah sangat dipengaruhi oleh penyimpanan benih tersebut. Daya kecambah $90 \%$ atau lebih merupakan syarat untuk mendapatkan bibit yang baik. Selain daya kecambah, bibit tembakau yang baik dan sehat diperoleh dari tanah pesemaian yang subur. Oleh karena itu untuk mendapatkan bibit tembakau yang berkualitas baik, media 
pesemaian merupakan faktor yang penting.

Media merupakan tempat berkembangnya akar dan hampir semua unsur hara yang dibutuhkan tanaman diserap melalui akar.

Unsur hara yang sangat diperlukan oleh bibit adalah nitrogen karena diperlukan oleh tanaman dalam jumlah yang relatif banyak, sementara nitrogen mudah hilang karena pelindian atau penguapan. Tanggapan tanaman terhadap kebutuhan nitrogen dipengaruhi oleh bermacam-macam faktor seperti: $\mathrm{pH}$ tanah, kadar unsur hara dalam tanah, keadaan air dalam tanah, keadaan fisik, kimia, dan biologi tanah (Rifa'i, 1982). Unsur hara yang diperlukan di pembibitan dapat diperoleh dari bahan organik.

Bahan organik yang dapat diberikan pada media pembibitan diantaranya adalah limbah padi dan pupuk kandang. Limbah padi yang paling utama dan dapat digunakan sebagai pupuk adalah jerami padi, dedak dan sekam. Selain limbah padi, pupuk kandang juga dapat digunakan sebagai media pembibitan. Pupuk kandang yang digunakan dapat berasal dari berbagai macam kotoran hewan yang kandungan unsur haranya berbeda-beda terutama unsur hara makro N, P, dan $\mathrm{K}$.

Limbah padi dan pupuk kandang mempunyai pengaruh yang lebih menguntungkan dibandingkan dengan pupuk alam maupun pupuk buatan lainnya. Disamping menambah unsur hara makro dan unsur mikro, juga dapat memperbaiki sifat fisik, kimia, dan biologi tanah, sebagai penyangga kation, pengektrasi asam humat, meningkatkan kation dapat dipertukarkan, dan merangsang pertumbuhan mikoorganisme. Oleh karena itu perlu dilakukan penelitian yang bertujuan untuk mengetahui pengaruh limbah padi dan pupuk kandang terhadap pertumbuhan bibit Tembakau Virginia.

\section{BAHAN DAN METODE}

Penelitian dilakukan di lahan percobaan yang terletak di Pakis, Delaggu, Klaten. Bahan yang digunakan adalah benih tembakau Virginia, jerami, dedak, sekam, pupuk kandang sapi, pupuk kandang kambing, pupuk kandang ayam. Alat yang digunakan antara lain ember, cetok, polibag, timbangan elektrik, penggaris, oven, jangka sorong, alat tulis.

Penelitian dilaksanakan dengan metode percobaan dalam pot faktorial $3 \times 4$ yang disusun dalam Rancangan Acak Lengkap. Faktor pertama yaitu macam limbah padi terdiri atas tiga jenis yaitu jerami, dedak, dan sekam. Faktor kedua yaitu empat macam pupuk kandang (PPK) yaitu tanah (control), tanah + PPK sapi, tanah + PPK kambing, tanah + PPK ayam, sehingga diperoleh 12 kombinasi perlakuan. Tiap kombinasi perlakuan terdiri atas 3 polibag dan masing-masing kombinasi perlakuan diulang tiga kali.

\section{HASIL DAN PEMBAHASAN}

Tabel 1. Rerata Tinggi Bibit (cm), Panjang Daun (cm), Lebar Daun (cm), Diameter Batang (cm), Jumlah Daun, Berat Segar Bibit (g), Berat Kering Bibit (g)

\begin{tabular}{lccccccc}
\hline Perlakuan & $\begin{array}{c}\text { Tinggi } \\
\text { Bibit } \\
(\mathrm{cm})\end{array}$ & $\begin{array}{c}\text { Panjang } \\
\text { Daun } \\
(\mathrm{cm})\end{array}$ & $\begin{array}{c}\text { Lebar } \\
\text { Daun } \\
(\mathrm{cm})\end{array}$ & $\begin{array}{c}\text { Diameter } \\
\text { Batang } \\
(\mathrm{cm})\end{array}$ & $\begin{array}{c}\text { Jumlah } \\
\text { Daun }\end{array}$ & $\begin{array}{c}\text { Berat } \\
\text { Segar } \\
(\mathrm{g})\end{array}$ & $\begin{array}{c}\text { Berat } \\
\text { Kering } \\
(\mathrm{g})\end{array}$ \\
\hline Limbah Padi & & & & & & \\
\hline Jerami & $9,87 \mathrm{a}$ & $12,53 \mathrm{~b}$ & $6,08 \mathrm{a}$ & $1,64 \mathrm{a}$ & $4,35 \mathrm{a}$ & $43,71 \mathrm{a}$ & $3,95 \mathrm{a}$ \\
Dedak & $9,31 \mathrm{~b}$ & $11,32 \mathrm{ab}$ & $5,24 \mathrm{~b}$ & $1,59 \mathrm{a}$ & $4,05 \mathrm{a}$ & $42,25 \mathrm{~b}$ & $3,51 \mathrm{~b}$ \\
Sekam & $9,49 \mathrm{ab}$ & $10,69 \mathrm{a}$ & $5,46 \mathrm{~b}$ & $1,67 \mathrm{a}$ & $4,15 \mathrm{a}$ & $42,34 \mathrm{c}$ & $3,59 \mathrm{c}$ \\
\hline Pupuk Kandang & & & & & & \\
\hline Tanah & $6,66 \mathrm{a}$ & $7,16 \mathrm{a}$ & $5,07 \mathrm{c}$ & $1,63 \mathrm{~b}$ & $3,23 \mathrm{a}$ & $39,66 \mathrm{a}$ & $3,09 \mathrm{a}$ \\
Sapi & $7,46 \mathrm{~b}$ & $10,53 \mathrm{~b}$ & $5,59 \mathrm{~b}$ & $1,77 \mathrm{~b}$ & $4,03 \mathrm{~b}$ & $41,46 \mathrm{~b}$ & $3,25 \mathrm{ab}$ \\
Kambing & $9,47 \mathrm{~b}$ & $13,71 \mathrm{c}$ & $5,58 \mathrm{~b}$ & $1,46 \mathrm{a}$ & $4,42 \mathrm{c}$ & $43,85 \mathrm{c}$ & $3,37 \mathrm{bc}$ \\
\multicolumn{1}{l}{ Ayam } & $14,65 \mathrm{c}$ & $14,64 \mathrm{~d}$ & $6,12 \mathrm{~b}$ & $1,65 \mathrm{~b}$ & $5,05 \mathrm{~d}$ & $46,10 \mathrm{~d}$ & $4,65 \mathrm{c}$ \\
\hline
\end{tabular}

Keterangan : Nilai rerata yang diikuti dengan huruf yang sama menunjukkan tidak ada beda nyata berdasarkan sidik ragam $5 \%$

Berdasarkan hasil uji jarak berganda Duncan pada table 1 terlihat bahwa perlakuan jenis limbah padi dan macam pupuk kandang menun- 
jukkan ada beda nyata. Hasil menunjukkan bahwa pemberian jerami pada media pembibitan tembakau menghasilkan tinggi bibit yang tertinggi dibandingkan dengan pemberian sekam dan dedak. Hal ini disebabkan karena jerami mengandung unsur $\mathrm{N}, \mathrm{P}$, dan $\mathrm{K}$ yang lebih tinggi dibandingkan sekam atau dedak. Campuran jerami dan kotoran ternak mempunyai nilai sebagai pupuk karena terjadinya penurunan $\mathrm{C} / \mathrm{N}$, sehingga menjadi lebih bermanfaat bagi pertumbuhan tanaman.

Dengan cukup tersedianya nitrogen maka pertumbuhan bibit tembakau dapat berlangsung dengan baik, mengingat nitrogen merupakan unsur yang diperlukan pada pertumbuhan vegetatif tanaman sehingga akan menperbanyak terbentuknya ranting dan daun. Dengan bertambahnya nitrogen dalam jumlah yang cukup maka akan dihasilkan protein yang lebih banyak daun-daun menjadi lebih lebar sehingga proses fotosintesis dapat berlangsung dengan baik (Saifudi Sarif, 1995).

Peranan nitrogen bagi tananam yaitu untuk merangsang pertumbuhan tanaman secara keseluruhan khususnya batang dan daun. Menurut Sri Setyati Haryadi (1979) bahwa taanaman yang berbatang basah memerlukan suatu dominasi dari fase vegetatifnya selama tahap pertama hidupnya.

Media pembibitan yang tersusun atas campuran tanah, pupuk kandang sapi dan pasir memberikan hasil tinggi bibit yang terendah.

Diduga hal tersebut disebabkan karena proses penyerapan unsur hara oleh bibit tembakau berjalan lambat. Pupuk kandang sapi tergolong pupuk kandang dingin. Proses pematangan pupuk berlangsung lambat, sehingga lambat pula dalam proses pelepasan unsur hara yang dikandungnya. Lambatnya proses pelapukan ini disebabkan karena sifat pupuk padat yang banyak mengand- ung lendir dan air. Adanya lendir menyebabkan pupuk berkerak bila terkena udara (bagian luarnya mengeras) sehingga proses oksidasi dalam pupuk berjalan lambat karena air dan udara sulit masuk kedalamnya (Setyamidjaya, 1996). Penambahan pupuk kandang ayam pada media pembibitan menghasilkan penambahan panjang daun bibit tembakau terpanjang yang kemudian diikuti oleh pupuk kandang kambing dan sapi. Hal ini disebabkan karena kandungan nitrogen pupuk kandang ayam lebih tinggi dibandingkan dengan pupuk kandang kambing serta sapi, dimana unsur nitrogen sangat berperan dalam proses pertumbuhan vegetatif tanaman. Sejalan dengan pendapat Setyamidjaya (1996) yang menyatakan bahwa nitrogen berperan dalam merangsang pertumbuhan vegetatif tanaman.

Leopold dan Kriedeman (1975) mengemukakan bahwa dengan terpenuhinya unsur nitrogen maka fungsi fisiologis sel akan terpelihara, khususnya daun tanaman yang paling tanggap terhadap ketersediaan unsur nitrogen sehingga akan menghasilkan jumlah daun yang lebih banyak. Tanaman yang pertumbuhan daunnya baik akan mencapai laju fotosintesis yang tinggi, berarti akan meningkatkan asimilat yang lebih banyak dan akan ditranslokasikan ke seluruh tubuh tanaman.

Jerami dan pupuk kandang ayam mempunyai kandungan nitrogen yang lebih tinggi dibandingkan dengan perlakuan jenis limbah padi dan pupuk kandang yang lain. Nitrogen merupakan unsur hara utama bagi pertumbuhan tanaman dan dibutuhkan dalam jumlah yang banyak sebab merupakan penyusun semua protein dan asam nukleat. Nitrogen mempunyai pengaruh yang paling cepat dan menonjol yang mula-mula cenderung meningkatkan pertumbuhan di atas tanah. Nitrogen dapat merangsang pertumbuhan vegetatif tanaman, penyusun khlorofil, protein 
dan lemak serta meningkatkan perkembangan jaringan hidup, mendorong pertumbuhan daun dan batang pada fase awal dan pertengahan pertumbuhan (Setyamidjaya, 1996).

Berdasarkan hasil uji dengan duncan multiple range test pada taraf 5\% menunjukkan bahwa rerata berat kering tertinggi dicapai oleh perlakuan jenis limbah padi berupa jerami dan pupuk kandang ayam. Hal ini disebabkan karena kandungan unsur hara nitrogen pada jerami dan pupuk kandang ayam lebih besar dibandingkan dengan perlakuan yang lain. Unsur nitrogen berperan penting dalam pembentukan hijau daun yang berguna sekali dalam proses fotosintesis. Fotosintesis menghasilkan karbohidrat yang ditimbun dalam tubuh tanaman. Ketersediaan nitrogen juga berpengaruh terhadap berat kering tanaman yang merupakan hasil penimbunan bahan kering bagian vegetatif dari proses fotosintesis. Oleh karena itu tanaman yang pertumbuhan daunnya baik akan mempunyai laju fotosintesis yang tinggi sehingga mampu menghasilkan bahan kering yang tinggi pula.

\section{SIMPULAN}

1. Penambahan limbah padi dan pupuk kandang pada media pembibitan berpengaruh nyata meningkat pertumbuhan bibit tembakau.

2. Tidak terjadi saling pengaruh antara penambahan limbah padi dan pupuk kandang pada media pembibitan dalam meningkatkan pertumbuhan bibit tembakau.

3. Penggunaan jerami padi dan pupuk kandang ayam menghasilkan pertumbuhan bibit tembakau yang terbaik.

\section{DAFTAR PUSTAKA}

Abdullah dan Soedarmanto, 1979. Budidaya Tembvakau. C.V. Yasaguna. Jakarta. 161 hal.

Afandie Rosmarkam dan Nasih Widya Yuwono, 2002. IImu Kesuburan Tanah. Kanisius. 224 hal.
Fitter, A.H,dan R. K. M. Hay. 1998. Fisiologi Lingkungan tanaman. Penerjemah Sri Andini, E.D Purbayanti.UGM Press. Hal 123, 143, 150,151,283.

Gardner, F.P, R. Brent Pearce dan Goger,L. M 1991. Fisiologi Tanaman Budidaya. Ul-Press. Jakarta. 428 hal.

Goldwortthy P.R. and N.M. Fisher, 1987. The Physiology of Tropical Field Crop. John Wiley and Sons Ltd. 874 p.

K.A. Wijaya, 2008. Nutrisi Tanaman Sebagai Penentu Kualitas Hasil dan Resistensi Alami Tanaman. Prestasi Pustaka. 121 hal.

Mul Mulyani Sutejo, 1997. Pupuk dan Cara Pemupukan. Rineka Cipta. 177 hal.

Rachman Sutanto, 2002. Penerapan Pertanian Organik. Kanisius. 219 hal.

Soenarto Adisoemarto1994. Dasar-Dasar Ilmu Tanah. Erlangga. 374 hal. 